\title{
The Origins, Processes and Emerging Outcomes of Neighbourhood Redevelopment in Gaziosmanpaşa, Istanbul
}

\author{
By Zeynep Ayşe Gökşin * \\ Yasemin Erkan Yazıcl \\ Evrim Töre
}

Large scale neighbourhood redevelopment programmes are emerging in Turkish cities which are implementing a national policy commitment to the demolition and replacement of 6 million earthquake vulnerable homes, over a period of 20 years. This phenomenon is analysed with particular references to the Istanbul Municipal District of Gaziosmanpassa. The homes affected are mainly in poor, illegally developed, gecekondu neighbourhoods which are the legacy of the explosive post-war urbanisation. In the aftermath of the devastating 1999 Marmara earthquake, the Turkish authorities initiated the development of the legal and institutional framework for neighbourhood redevelopment which culminated in the Urban Regeneration Law of 2012. This was a controversial process which included several projects that were heavily criticised for causing displacement, dispersal and forced evictions. The case study of the on-going redevelopment of the Sarigöl neighbourhood identifies the processes which continue to generate these negative outcomes and sustained opposition from residents, professional bodies and academics.

Keywords: displacement, Gaziosmanpaşa, Istanbul, neighbourhood redevelopment, participation

\section{Introduction}

During the past three years or so, large scale neighbourhood redevelopment programmes have emerged in Turkish cities which are implementing a national policy commitment to the demolition and replacement of 6 million earthquake vulnerable homes, over a period of 20 years. Most of these dwellings were the product of the explosive post-war growth of Turkish cities when the population of Istanbul increased from 1 million people in 1950 to 5 million in 1980 and 14 million in 2014. Much of this growth was accommodated through mainly illegal development on earthquake vulnerable land. In the 1950s low income immigrants from rural areas housed themselves in squatter settlements - gecekondus. From the late 1960s, 4-6 storey apartment blocks dominated housing provision in both redeveloped squatter houses and in new neighbourhoods, as peripheral urban land was opened up to

\footnotetext{
${ }^{*}$ Lecturer, Istanbul Kültür University, Turkey.

${ }^{\dagger}$ Lecturer, Istanbul Kültür University, Turkey.

* Lecturer, Istanbul Kültür University, Turkey.
} 
construction. Since the enactment of a new legislation in 2012 increasing numbers of these poor neighbourhoods are being designated as Urban Regeneration Areas (URAs) by central government and local municipalities.

This new national policy marks the beginning of a new era of state intervention in Turkish post-war urbanisation. But at the turn of the century urban and neighbourhood regeneration was not on the urban policy agenda. Its origins can be traced back to the 1999 Marmara earthquake which killed 18,000 people, hospitalised a further 40,000 and left 300,000 dwellings destroyed or seriously damaged. This catastrophe was initially dubbed a 'wakeup' call for the Turkish authorities, as it tragically revealed the life-threatening nature of the legacy of $20^{\text {th }}$ century urbanisation (Gibson et al. 2010). In this context, the need for the demolition and the re-building of hundreds of neighbourhoods in Istanbul alone was widely acknowledged. But it took over a decade to complete the development of the legal and institutional framework because during this process of policy evolution the first examples of the implementation of neighbourhood redevelopment projects were highly controversial. Growing opposition was based on the view that neighbourhood redevelopment would inevitably result in "planned gentrification" which destroys established communities by displacing and dispersing the majority of the poor residents.

When this decade-long process of policy evolution culminated in the Urban Regeneration Law of 2012 the new powers and formal procedures were warmly welcomed by the construction sector but heavily criticised by a range of academic policy analysts, professional bodies and community activists. In this context this article argues that it is vital that the rapidly emerging neighbourhood redevelopment programmes should be systematically evaluated. Research is needed which identifies their costs and benefits, with a focus on the outcomes for the communities affected, and the need to develop reforms which minimise negative social impacts.

Thus the aim of this article is to critically analyse the emergence of the current and expanding neighbourhood regeneration programmes, with a particular reference to a case study of the Istanbul Municipal District of Gaziosmanpaşa. The next section briefly reviews the wide range of published research which has described and analysed post-war Turkish urbanisation. The specific focus of this review is to identify those aspects of the legacy of urbanisation which explain why large-scale neighbourhood regeneration is both necessary, but inherently controversial, because of the complex patterns of property ownership which were created during the post-war period.

The third section draws on a literature review to develop an analysis of the evolution of national policy and the legal and institutional framework. This focuses on the interrelated development of three major laws and the administrative re-structuring of key public agencies. The first two laws were the basis of highly controversial neighbourhood regeneration projects in Istanbul, which fuelled the debate about the pros and cons of neighbourhood redevelopment. The Urban Regeneration Law of 2012 now provides the powers and procedures for the rapid expansion of neighbourhood 
redevelopment, but the ongoing opposition about its potential impact is clearly rooted in the experience of earlier high profile projects.

Thus the fourth section reviews the literature which analyses the experience of the controversial redevelopment of the Istanbul neighbourhoods of Ayazma, Sulukule and Tarlabaşı. These projects were developed and implemented in the context of a debate about the need for and likely the consequences of large-scale, commercially driven mixed-use "prestige" projects. The section concludes by highlighting the need for and the emergence of a new field research which aims to evaluate the neighbourhood redevelopment programmes now being implemented by municipalities using the powers and procedures provided by the 2012 Law particularly in areas outside high value central city locations vulnerable to gentrification.

The $5^{\text {th }}$ section presents and discusses the interim findings of a case study which is conceived of as contributing to this emerging area of research. This case study analyses the implementation of the Sarıgöl-Yenidoğan Urban Renegeneration Area (URA) in the Istanbul Municipal District of Gaziosmanpaşa, which was designated in November 2013. The project is being undertaken by the authors at the Kültür University, Istanbul (TÜBİTAK, The Scientific and Technological Research Council of Turkey- Project no. 114K626). The progress of the research to date has demonstrated not only the need for, but also the very real practical challenges of evaluating the controversial implementation of the URA. The interim results of the research suggest that whilst redevelopment will physically restructure the neighbourhood, the different social groups which have lived side-by-side in the area for many years are being displaced and dispersed by being forced to leave their homes and lives in the neighbourhood. The paper identifies, analyses and discusses the processes which are generating these negative outcomes, with particular reference to the limited extent to which residents are involved in key decisions and the absence of affordable re-housing opportunities for many low income flat owners and all tenants.

The conclusions focus on the need for changes in policy, procedures and resource allocation which will mitigate the adverse impacts of the current implementation of the URAs. These would involve the evolution of a more participatory approach to neighbourhood regeneration to evolve, underpinned by the provision of a range of re-housing options which match the diverse needs and resources of the residents living in designated URAs.

\section{The Legacy of Post-war Urbanisation in Turkey}

The urbanisation processes which structured the explosive growth of Turkish cities were characterised and dominated by illegal residential development, many on earthquake vulnerable land. The legacy of these informal urbanisation processes is the need for the demolition and replacement of millions of poor quality apartments in low income neighbourhoods. This section draws on a review of the wide range of literature (Tekeli 1994a, Keleş 
1997, Buğra 1998, Keyder 1999, Özden 2008, Türkün 2014) to identify the conditions which make the regeneration of these neighbourhoods a particularly challenging process.

Beginning in the 1950s and continuing through the 1960s and 1970s until the early 1980s, the state-led industrialization process in Turkey encouraged massive migration from Anatolia to the big western cities, particularly to Istanbul, Ankara and Izmir. The migrants could not afford legally constructed houses and the state could not respond to their housing problems by providing affordable houses. Therefore, the migrants generated their unique solution to the problem: gecekondu (literally "built overnight") which are single storey squatter houses of very poor quality built by the migrants themselves, at low densities (included gardens) on under-used land usually owned by the state.

The state responded to the problem of illegal gecekondu developments by a series of Amnesty Laws which institutionalised patronage by supporting and protecting gecekondu residents who illegally settled on public land in exchange for their votes. The most significant was the 1966 Gecekondu Law no.775. Like its predecessors, its aims were the improvement, demolition and prevention of gecekondu developments (Keleş 1997). Although gecekondu policy should have included social, economic and physical dimensions of gecekondu development, the law only dealt with the regulation of construction through minimum building standards.

Additionally in this era, land outside municipal boundaries could be divided by Title Deeds Offices upon applications by land brokers without requiring any subdivision regulation. This enabled a huge number of small plots to be formed and gecekondu development was encouraged on these newly formed plots (Tekeli 1994a, Tekeli 1994b). In the 1970s, when urban land in gecekondu areas was included within extended municipal boundaries, land brokers could not easily get plots divided or merged through Title Deed Offices. So they started to sell the agricultural land on the urban peripheries via shared land deeds.

This type of development was made possible via a process called the "share of construction" (also known more recently as build-sell). In this process, small developers negotiate with the owners of empty lots, single storey gecekondu dwellings to redevelop their land for multi-storey apartment blocks. On the completion of construction the new dwellings are shared between the owners and the developers (Enlil 2011).

In 1965, the state enacted the Flat Ownership Law which enabled the ownership of a single flat in an apartment block which provided the legal framework for the share of the construction system. This system then dominated housing provisions in Turkey, in both gecekondu and planned areas until the end of the 1970s (Tekeli 1994a).

Thus from the late 1960s, building gecekondus gained a different meaning. They were no longer built simply for shelter, but to create capital assets which could be traded as commodities. As a consequence of the security of ownership given to gecekondu residents by this policy, a major market in gecekondu dwellings emerged (Özden 2008). 
During the 1980s, four more Amnesty Laws were enacted, including the 1983 Amnesty Law no. 2981, which required Improvement Plans to be made in gecekondu areas (Dündar 2001, Özden 2008). Gecekondu residents had to apply to government licensed private technical offices to get pre-title deeds which would be changed to title deeds after the municipality made the Improvement Plans for the area. But not all residents could afford to pay and make their applications correctly to obtain their pre-title deeds. Thus some residents ended up with title deeds, some with pre-title deeds and some with no deeds at all (AGFE 2009).

Two major outcomes of these urbanisation processes have had a major impact on the evolution of the legal and institutional framework for neighbourhood redevelopment programmes and the controversial outcomes of current implementation processes.

The first outcome is the variety of neighbourhoods which, to varying degrees, are earthquake vulnerable. The following typology has been adapted from Gökşin (2008) which drew on Özden (2008: 310-311):

- Historic pre- $20^{\text {th }}$ century neighbourhoods which are in decline, most of which are high earthquake risk areas, many of which are in central locations which are becoming increasingly vulnerable to gentrification

- Traditional 1950s gecekondu neighbourhoods, self- build, single storey, usually single family dwellings - now a residual category of poor neighbourhoods which are being redeveloped.

- Redeveloped gecekondu areas produced by the "share of construction" system since the late 1960s. These neighbourhoods are dominated by high density 4-6 storey apartment blocks, which have deteriorated over time, a high proportion of which are vulnerable to earthquake risk.

- Planned neighbourhoods outside the above areas, which are better quality and have been built on privately owned land, also through the share of the construction system but in compliance with statutory plans. Some of these are earthquake vulnerable but here redevelopment is operating at an individual block level rather than at the neighbourhood level, as in URAs.

The second outcome is the complexity of ownership rights at the level of the individual apartment and at block level. As a result of this urbanisation process, the issue of legitimate ownership is by no means simple because the occupancy of a single apartment can be under any of the following conditions

- owner-occupiers with full title

- absentee owners with full title renting out their apartment(s)

- "owner" occupiers with pre-title deeds only

- absentee "owner" occupiers with pre-title deeds renting out their apartment(s) 
- occupiers with various documents which they believe give them legal property rights such as shared land deeds and zoning status documents to be updated to pre-title deeds

At apartment block level there can be any combination of these flat "ownerships" with different levels of property rights and therefore an extremely complex pattern of property rights in each block. Moreover, Turkish inheritance laws require owners to divide their estate between all their children. Thus many of these individual apartments have more than one person with an interest in the property - the shareholder living in the apartment may be only one of many shareholders who live elsewhere.

A crucial issue is that, particularly in poorer quality apartment blocks in deteriorating neighbourhoods, there are many tenants who have no property rights and many occupants with only informal rights which may not be accepted as legitimate and legally enforceable. This issue presents itself in all the types of neighbourhoods categorised above albeit to varying degrees. But, it is at its most challenging in gecekondu areas, both traditional and redeveloped.

Neighbourhood redevelopment requires restructuring of this complex array of property rights and ownership patterns. These rights have to be identified and taken into account in the re-housing process which provides replacement accommodation for residents whose homes are demolished.

Thus the overall outcome of this $20^{\text {th }}$ century urbanisation process was a complex pattern of (often contested and uncertain) property rights in poor quality apartment blocks in deteriorating and often earthquake vulnerable neighbourhoods which have now become the target areas for 21st century neighbourhood redevelopment. This is the challenging legacy which policy makers faced as they confronted the task of establishing an effective legal and institutional framework work which would enable action programmes to deliver the demolition and replacement of millions of apartments.

\section{A Decade-Long Evolution of a Legal and Institutional Framework for Urban Regeneration}

The target of the national urban regeneration policy was announced in 2012 as the demolition of 6 million poor quality earthquake vulnerable dwellings across Turkey (Güneş 2012). However, it was in the aftermath of the 1999 Marmara earthquake that urban and neighbourhood regeneration became a significant component of the Turkish urban policy agenda. Since the early 2000s a new legal and institutional framework for urban regeneration has been established in a decade long process which introduced a series of new laws, accompanied by the restructuring of key public agencies. Three major laws were enacted: Municipal Law, Renewal Areas Law and Urban Regeneration Laws. 
The first Draft Urban Regeneration Law was published in 2005. It was criticized heavily by professionals mainly because there was no priority targeting to earthquake vulnerable neighbourhoods; and no provision for a strategic approach. Mayors could designate areas virtually anywhere and without reference to formal, legal master plans. There was no provision for rehousing tenants, minimum provision for community participation and an almost exclusive focus on physical regeneration (Gökşin 2008, Gibson and Goksin 2009). This law did not get past the draft stage. However, in 2005, two laws were approved which provided some of the powers which were included in the Draft Urban Regeneration Laws. These were Municipal Law no. 5393 and Renewal Areas Law no. 5366.

Article 73 of Municipal Law no. 5393 was approved in 2005, then modified and extended in 2010. In its final form, it provided municipalities with powers to designate URAs of 5-500 hectares in size, implement regeneration projects to redevelop or restore old neighbourhoods, change their function to commercial and industrial purposes, create new residential neighbourhoods and/or take measures against earthquake risk. Municipalities also gained powers to specify building height and densities in these areas. Urban regeneration projects in this context were typically implemented through a partnership with the central government agency, the Mass Housing Administration (TOKI) which redeveloped the existing building stock through a "demolish/rebuild" method (Kuyucu and Ünsal 2010). The Mayor of the Küçükçekmece District in Istanbul was one of the few Mayors who used this legislation to implement the redevelopment of the traditional gecekondu neighbourhood of Ayazma.

Law on Renovating, Conserving and Actively Using Dilapidated Historical and Cultural Immovable Assets Law no. 5366 provided powers for local municipalities to designate Renewal Areas (RAs) in designated Conservation Areas, identify urban infrastructure requirements and specify construction standards to meet earthquake safety requirements, prepare a phased programme of projects to be approved by a government appointed Regional Conservation Board and then implemented in the area, and establish project organization and management arrangements, and take measures to ensure local residents' participation in this process (Gibson and Goksin 2009). The Fatih Disrict of Istanbul includes the Historic Peninsula. The Fatih Mayor, in partnership with TOKI, used this legislation as a basis of a neighbourhood regeneration strategy and programme, which included the internationally controversial demolition and the rebuilding of the traditional gecekondu neighbourhood of Sulukule. In parallel, this legislation was also used by the Mayor of Beyoğlu to redevelop a run-down area of $19^{\text {th }}$ century apartment blocks in the Tarlabaş1 neighbourhood adjacent to Taksim square.

Via numerous legal reforms between 2002 and 2008, the government restructured the powers and resources of TOKI. It was made the sole agency for regulating the zoning and sale of all state-owned urban land, except military land. It was also given the power to build "for-profit" housing on state land either by its own subsidiary firms or through public-private partnerships, in 
order to raise revenues for subsidised housing construction in Urban Regeneration Areas. Finally, TOKI was given the power to revise statutory development plans and expropriate property in gecekondu areas (Kuyucu and Ünsal 2010). Thus through the 2000s most of the early neighbourhood redevelopment projects were implemented through a partnership between local municipalities and TOKI.

However, in June 2011, the Ministry of Redevelopment and Settlement was restructured to become the Ministry of Environment and Urbanism (MEU). In a major centralisation process, the new Ministry was given powers which originally rested with local authorities, including making and approving statutory development plans, approving projects, giving building and occupancy permits, and expropriating property (ŞPO 2011).

The culmination of the evolution of the legal and administrative framework was the approval in May 2012 "The Law of Transformation of Areas under the Disaster Risks no. 6306" conventionally referred to as the Urban Regeneration Law. The officially stated intention of this legislation is to give priority to improvement, clearance and renewal of disaster (mainly earthquake) vulnerable areas and buildings. All powers for URAs rest with the Ministry, but can be delegated to metropolitan or district municipality (Official Gazette 2012). Thus this law makes neighbourhood redevelopment a function of a partnership between central government and local municipalities, with the central government as the dominant partner.

The law gives powers to the MEU to designate "risky areas" as URAs in response to applications by metropolitan or district municipalities and subject to the approval of the Council of Ministers. MEU also now has the power to designate "reserve areas" in which new neighbourhoods can be developed as transfer areas for re-housing residents from URAs for whom on-site housing cannot be provided. The third important provision of the legislation is the power to order the demolition of "risky buildings" which have been assessed as earthquake vulnerable.

According to the law, all technical and planning analyses, including earthquake vulnerability surveys of buildings have to be prepared by the municipalities before application. After designation, formal development and implementation plans, urban design projects have to be prepared by the municipality. The law requires resident participation in the implementation process, but this is limited to developers and construction companies negotiating with the owners. In the context of an updated model of the share of construction process, this negotiation centres on agreeing on a deal which determines the share of construction which goes to the property owners, according to their property rights, and that which goes to the construction company and determines its rate of profit. During the demolition and construction period, financial support in various forms is provided to residents who have "legitimate" property rights. This support includes the reduction of VAT on construction from $18 \%$ to $1 \%$ and rent support to owners to pay for temporary re-housing during the demolition and re-building of their homes through the share of construction process. But tenants have no rights to be re- 
housed, so they only receive temporary rent support and a contribution to moving expenses.

The new Urban Regeneration Law is now used to re-designate the existing urban regeneration areas designated under the previous legislation, in order to enable the MEU and the municipalities to use the new powers and resources.

The 2012 Urban Regeneration Law no. 6306 has intensified the decade long debate about the purposes and likely outcomes of neighbourhood redevelopment. Major criticisms of the earlier legislation were (and still are) held to be valid for the 2012 legislation. Amongst the critics, Balamir (2007) and Özden (2008) had underlined the lack of a strategic approach which meant that urban regeneration areas were designated outside formal planning processes because the urban regeneration legislation was a separate code and not integrated within the overall Development Law. Throughout the 2000s it was argued that neighbourhood redevelopment areas and transfer areas should be identified in the formal master plans so that there is a strategic approach, rather than the areas being designated for different reasons by different municipalities and agencies. Similarly the new legislation did not address the absence of re-housing for tenants, minimum resident participation and the lack of provision of neighbourhood community facilities.

However, the 2012 legislation apparently addressed the often voiced criticism of the failure to give priority to earthquake vulnerable neighbourhoods, not least through its official title for the The Law of Transformation of Areas under the Disaster Risks no. 6306 and the formal title of the target areas as 'risky areas'. But a major criticism is that the criteria for designation are not transparent. The validity of this criticism has been demonstrated by the fact that very few of the first wave of URAs that were designated since 2012 are in the high earthquake risk areas identified by the JICA study in 2002 (IBB-JICA 2002). Many are in relatively high market demand areas with a potential of very profitable housing development which existing residents cannot afford (Cumhuriyet Gazetesi 2015 - see Figure 1, orange areas designated by JICA, red areas designated by MEU; Özkan Eren and Özçevik 2015).

Figure 1. URAs Designated by MEU and Earthquake Risk Areas Identified by JICA Study

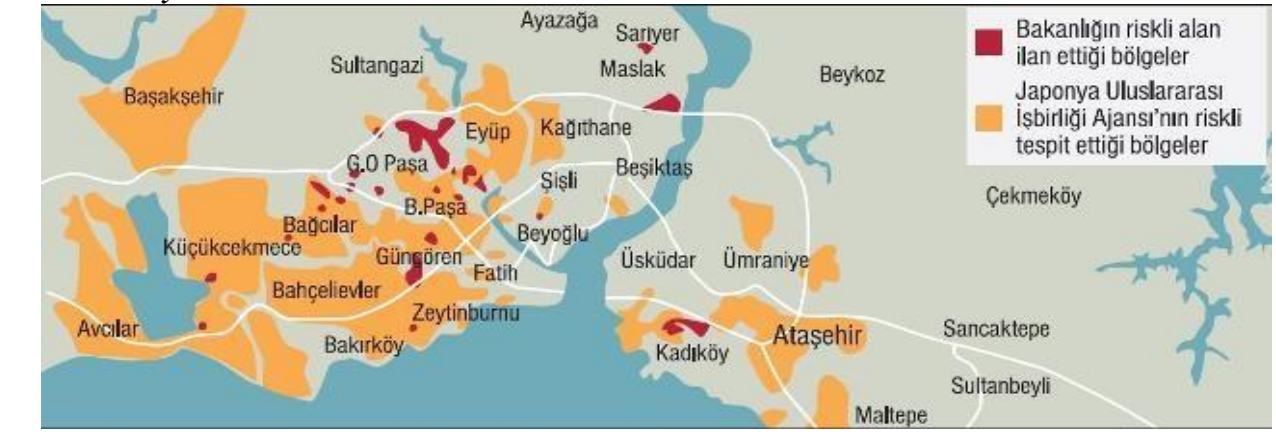

Source: Cumhuriyet Gazetesi 2015 
This analysis of the evolution of the current legal and institutional framework of urban regeneration in the early 2000s begs two important and related questions. Why did it take more than a decade from the 1999 Marmara earthquake to produce the 2012 framework which patently fails to deal with serious criticisms, many of which have been voiced consistently since the mid2000s? What will the implementation of neighbourhood redevelopment in contemporary URAs deliver and to whom?

\section{Early Experience of the Implementation of Neighbourhood Redevelopment}

Between 1999 and 2012, an increasing number of neighbourhood regeneration projects were developed and implemented using the evolving framework. However, most were highly controversial as they resulted in the displacement and dispersal of the residents in a process which came to be characterised as "planned gentrification" (Kocabas and Gibson 2011). The United Nations Advisory Group on Forced Evictions which visited Istanbul's 8 regeneration areas in 2009 reported that approximately 80,000 people were directly affected and 12,730 people had already had their homes destroyed see Figure 2 (AGFE 2009).

Figure 2. Forced Eviction Map, Istanbul 2009

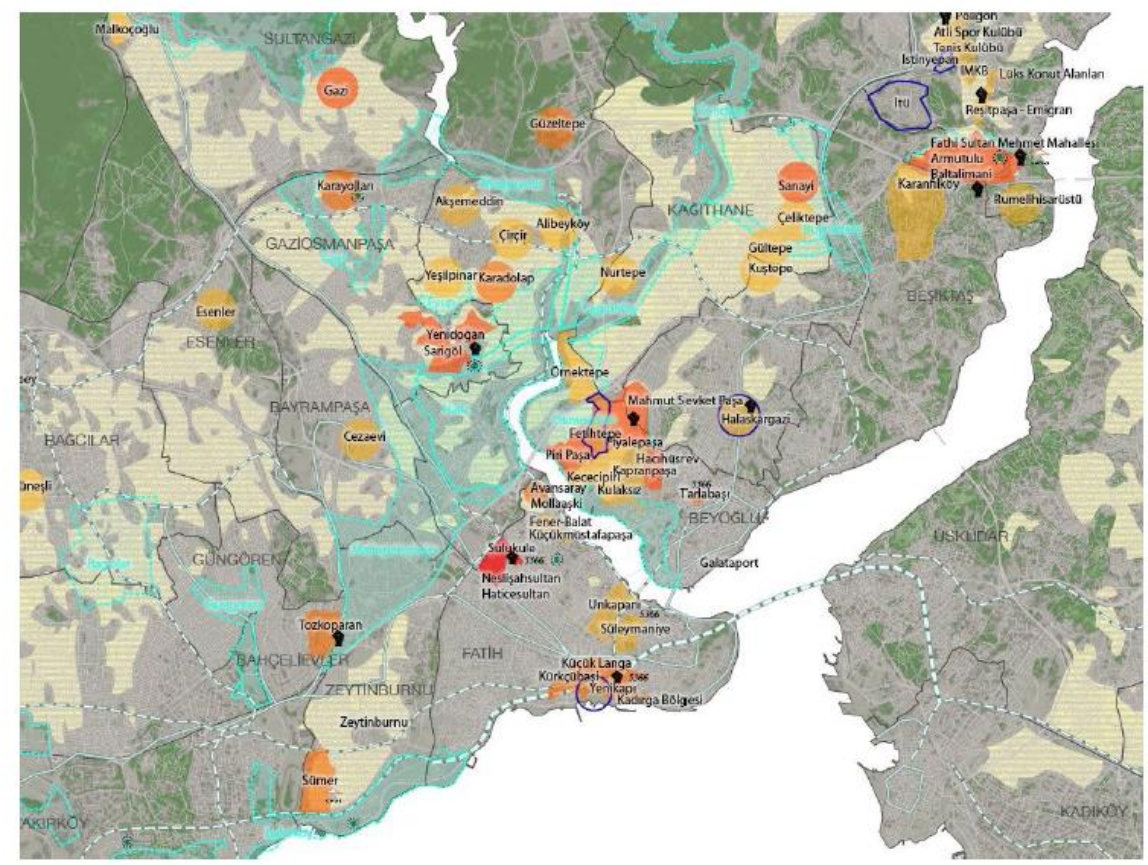

Source: AGFE Mission 2009: 30

The group found that although the legislation requires agreement by owners, both property owners and tenants experience displacement and forced relocation. Participation is restricted to negotiations in which owners are provided with only two options. They can sell their house for the compensation 
money offered by the municipality and move out, or they can sign agreements to purchase replacement houses in their neighbourhood, or elsewhere, although these agreements often put them under a lot of financial pressure. During negotiations, owners are often intimidated by "urgent expropriation decisions" issued by Municipalities to be used to secure "agreement" from reluctant owners. Thus implementation in these 8 areas has been inevitably controversial as the powers and procedures were applied in poor areas with complex patterns of ownership and in many cases high development value. These initial neighbourhood regeneration projects used the different laws as they emerged during the 2000s. This process and its outcomes can be analysed by reference to action on the ground in the contrasting neighbourhoods of Ayazma, Sulukule and Tarlabaşı.

The process in Ayazma began with a protocol signed by the Küçükçekmece Municipality, GIMM and TOKI in 2004 to provide housing within the district for local residents (Bezirganbahçe Estate) after the clearance of gecekondus (Gökşin 2008). In July 2005, the Ayazma-Tepeüstï Neighbourhoods were designated as URAs by the Municipality based on the Article 73 of the Law no. 5393. Some 120 tenant families in Ayazma were initially promised local rehousing by the district Municipality. But this was not offered during subsequent negotiations. After the demolitions, they lived in tents in the cleared area to force the Municipality to hold its promise. Families, who could move, moved out but 18 families remained in their tents for 3 years. The tents were demolished by the Municipality in 2009. The Mayor announced that the families would be allocated to houses in the Bezirganbahçe Estate with the same mortgage conditions previously offered to the owners, together with rent support for a year. But the rent support offer was subsequently withdrawn. In the end they were allocated to houses in the distant TOKI Kayabaşı Estate and on harder terms than the ones previously offered to the owners. The latest research revealed that their conditions remained uncertain (Türkün and Aslan 2014).

In the Ayazma Neighbourhood 52\% of the land was private property while $32 \%$ was publicly owned. In the Tepeüstï Neighbourhood, $90 \%$ of the land belonged to TOKI. After the existing gecekondu buildings were demolished, the area was turned over to Emlak Konut REIT by TOKI for development in three phases. Emlak Konut went out to tender in 2009 and commissioned a private construction firm to build new houses via the share of revenue process in the first phase. This phase included 17 blocks accommodating 3,080 residences and 20 twin villas in three sections. The blocks are between 18 and 32 storeys high. There is a swimming pool, a shopping centre and a golf club (Myworld-europe.com 2015). The new, relatively affluent owners of these expensive apartments in this gated community came from outside the redevelopment areas. According to the information on the website, the sale of all housing is complete. The tenders for the second and third phases were also completed but construction has not started yet.

Sulukule was an area of very poor quality housing adjacent to the historic city walls, which had been the home of a Roma community for over a thousand 
years. In April 2006, it was designated as an RA based on Law on Renovating, Conserving and Actively Using Dilapidated Historical and Cultural Immovable Assets Law no. 5366. Three months later, Fatih Municipality signed a Protocol with the Metropolitan Municipality and TOKI for the comprehensive redevelopment of the neighbourhood (Kocabas and Gibson 2011). Immediately, an "urgent expropriation decision" was issued. Under the threat of this decision, within three years, through a combination of negotiation and expropriation, the municipality acquired and demolished most of the dwellings in the area. A minority of property owners secured an agreement by which they purchased an apartment in the area after redevelopment. The value of their existing property constituted a down payment for their new property and they were required to pay the balance through a 15 year mortgage, starting at a low rate of interest which would increase every 6 months. In 2012, TOKI increased the selling price, putting more pressure on owners.

Rebuilding began in the summer of 2010 and was completed in 2013. Some of the 40 families out of 199 moved to the replacement housing in Sulukule in 2013. They are reported to be struggling with maintenance costs and mortgage payments and also with the new lifestyle (Can 2013). On the other hand, tenants with no property rights were not included in local rehousing projects. They were given some temporary rent and moving support and forced to move out. However, in some cases, tenants were given the opportunity to buy houses with long term mortgages in TOKI estates - usually high-rise blocks built in distant locations on the urban periphery. These estates have turned out to be problematic in many aspects. Mortgages and maintenance costs are not affordable for mainly low income tenants. They have been built with no community facilities, job opportunities or public transport links. Additionally, the quality of their construction is now raising serious concerns.

The majority of the residents in Sulukule were relocated to a TOKI estate $40 \mathrm{~km}$ away from the city centre. But 334 families out of 337 who had moved there left their new accommodation as they were unable to maintain mortgage payments (Kocabas and Gibson 2011). They moved back as tenants to areas surrounding Sulukule.

Tarlabaş1 was designated as an RA in 2006 also based on Law No. 5366. It was an area of dilapidated 19th century apartment blocks, close to Taksim Square with a high land value. It is a socially diverse area with a minority of long established owner occupiers, alongside a majority of tenants of mainly absentee landlords. A private company was contracted by the municipality in 2007 to design the projects. But the designs were initially kept hidden during negotiations with residents. A public exhibition in 2008 revealed that the size of the apartments to be built ranged from 35 to 75 square metres, too small for the majority of the Tarlabaşı's households (Oktem Unsal 2015). The first phase will be completed in 2018 , with only a small minority of the original residents being re-housed in the area (Gapinsaat.com 2015).

This continuously controversial experience during the 2000s meant that most municipal mayors saw major electoral risks in initiating neighbourhood redevelopment which discouraged all but the most entrepreneurial from using 
the evolving powers. This reluctance underpinned the government's unwillingness to give the issue a higher priority and provide more powers and resources to stimulate numerically significant programmes of neighbourhood redevelopment.

A combination of two factors overcame this reluctance - the negative impact of the global economic crisis on the volume of construction from 2008 and the Van earthquake in 2011. The downturn in construction was a major concern as it had a knock effect on the national economy which threatened the national growth strategy (Özkan Eren and Özçevik 2015). Thus the government moved to develop a legal and institutional framework to promote redevelopment activity which was consistent with its overriding neo-liberal economic and political perspectives and priorities. This meant that increased activity could only be promoted by creating a construction industry and market that led to a redevelopment process. Thus priority had to be given to designating those areas where new incentives could be applied to guarantee substantial profits for the construction industry. These would not necessarily be the most earthquake threatened areas.

The Van earthquake gave an additional impetus to this process. Moreover it provided an opportunity for a construction sector that led profit oriented and housing market driven processes to be legitimised and presented as a response to the earthquake threat. But the experience of the authoritarian "top-down" neighbourhood redevelopment processes implemented prior to the 2012 legislation was viewed by many critics as creating excessive profits for landowners and construction companies and on the other hand causing forced displacement, particularly of poor owners and tenants. This raises critical issues about the economic, spatial and social sustainability of the approach embodied in the new legislation (Töre 2015).

Since the passage of the 2012 Urban Regeneration Law 40 URAls have been designated in Istanbul. This marks a shift from the small number of neighbourhood projects in the recent decade to the prospect of a massive and accelerating programme of neighbourhood re-development. Given the continuing controversy, it is important that empirical research is undertaken to identify the actual, rather than the predicted outcomes of the application of the new powers and procedures. The ongoing case study in Gaziosmanpaşa has been conceived as a contribution to this emerging area of research - see Yalçıntan 2012, Kahraman 2013, Dülgeroğlu et al. 2013, Bektaş 2014).

This shift is now analysed by reference to the development of neighbourhood regeneration in Gaziosmanpaşa, Istanbul, within the evolving national legal and institutional framework with particular references to the controversial process of displacement and relocation of local residents in Sarı̈öl. 


\section{Urban Regeneration in Gaziosmanpaşa-Sarıgöl}

The neighbourhood selected for the case study selected is the SarigölYenidoğan URA in the Istanbul District of Gaziosmanpaşa. This section presents the case study by firstly explaining the rationale for the choice of the case study area and methodology. The urbanisation of Gaziosmanpaşa is then analysed to identify the legacy of this process which current policy makers have to deal with. This sets out the physical, social and economic conditions which constitute the challenges of urban regeneration in Gaziosmanpaşa. The implementation of the URA is then analysed in three stages from its origins in 2005.

\section{Methodology}

The rationale for the choice of Gaziosmanpaşa as the case study district has 3 components. First, the urban fabric of the municipality is dominated by redeveloped former gecekondus and as such is representative of the main type of areas which are being targeted by the new national policy launched by the government in 2012. Secondly, the Mayor has developed a strategic approach through a process which included the commissioning Foster Associates (UK) to prepare an Urban Regeneration Areas Master Plan. Finally, the 13 areas designated as URAs within the Master Plan framework by the end of 2014 constitute almost a third of the designations in the Greater Istanbul Metropolitan area.

Within this major programme the Sarıgöl-Yenidoğan URA has been chosen as the case study neighbourhood for two reasons. The first is that urban regeneration plans and projects have been developed over a number of years and this experience is being built on by the recent designation of the area as a URA under the new legislation. Secondly, within the URA the first phase of the redevelopment is about to be completed with construction of replacement housing and negotiations that are underway in the area of the next phase. This means that within the timescale of our research project we will be able to assess the key elements of the URA process: planning and design, the negotiations to agree to a deal with the owners as the basis of redevelopment, and the rehousing process prior to demolition.

The methodology designed for the case study comprised a variety of techniques, including face-to-face semi-structured interviews with representatives of relevant public agencies, private companies, local NGOs, residents, on-site observations, together with the analysis of plans, projects and documents prepared by related public/private agencies and articles in the media about the subject.

A questionnaire survey is planned as part of the case study, which was going to be conducted by a private company in the spring of 2015 . However the company reported that emotions were running high in the area at that time in a reaction to formal documents which had been recently delivered to the houses in the URA. Local people were feeling vulnerable and did not want to give information to strangers. So, the questionnaire was postponed until 
autumn of 2015. Some quantitative data has been acquired from publicly available public and private sector documents, reports in the media and face-toface interviews. But it was found that only limited statistical data is publicly available about the people who live in the URA and how they have been and are being affected by redevelopment. Much of the relevant data about the pattern of the residents' property rights and their re-housing options being made available must exist in the records of the construction company but it is not available since it is commercially confidential. Sarıgöl was investigated in undergraduate and graduate studies but these studies were undertaken before the new regeneration legislation was passed and thus have only limited value.

\section{The Urbanisation of Gaziosmanpaşa}

The development of Gaziosmanpaşa began when the Menderes government gave the Balkan refugees from Bulgaria and Yugoslavia government owned land in the area to build houses in 1950s. As industry began to expand in nearby Eyüp and Rami, the industrial workforce, mostly comprising rural migrants, started to illegally settle in Gaziosmanpaşa by building their gecekondu on nearby government owned land. Gaziosmanpaşa became the second major gecekondu area in Istanbul, following Zeytinburnu. By 1962, there were some 18,000 gecekondu houses which accommodated 90,000 people. Gaziosmanpaşa was separated from Eyüp and became a district in 1963 (Gaziosmanpaşa.bel.tr 2015).

Figure 3. Location of Gaziosmanpaşa in Istanbul

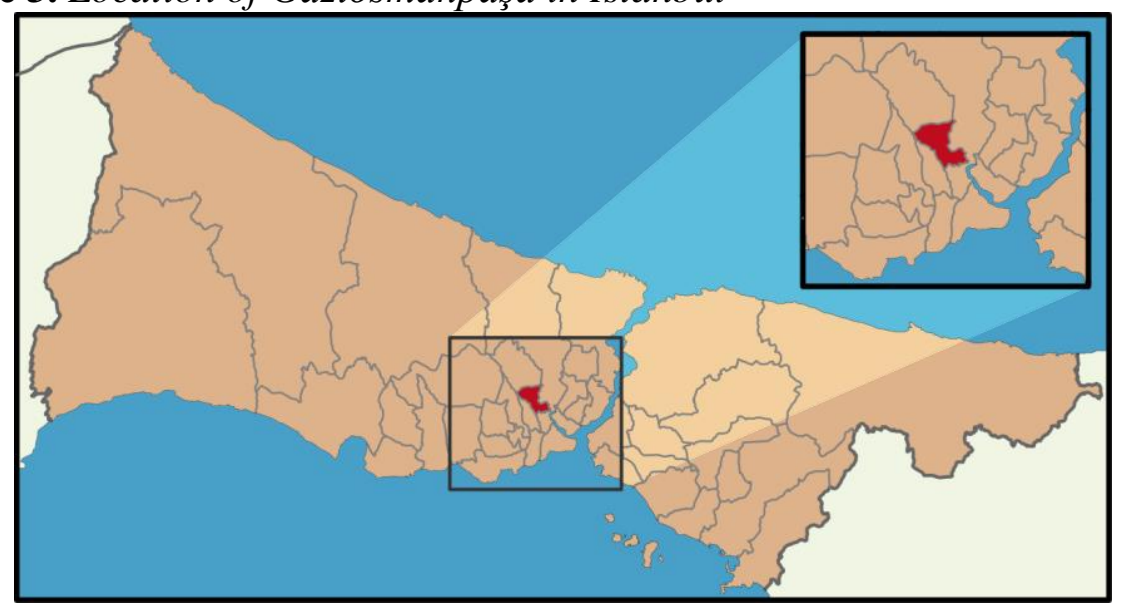

Source: Wikipedia 2015

By 2007, Gaziosmanpaşa's population was over 1 million and in 2009 it was divided into three districts and its population decreased to 460.000.

In 1992, an Improvement Plan was prepared which gave gecekondu buildings title deeds and pre-title deeds. The plan also made infrastructure improvements such as laying power, water and land lines.

In 2006, Gaziosmanpaşa was designated as a $2^{\text {nd }}$ tier urban centre in the Istanbul master plan which provided an incentive for investment. Across the district, increasing private investment in commercial projects is accompanied 
by public investment in physical and social infrastructure, together with plans and projects for redevelopment of gecekondu areas.

In 2005, Gaziosmanpaşa Municipality started to prepare plans and projects within designated URAs. Most recently, 13 URAs were designated based on 2012 Urban Regeneration Law no. 6306 (Figure 4).

Figure 4. Gaziosmanpaşa Designated URAs (Sarıöl no.12)

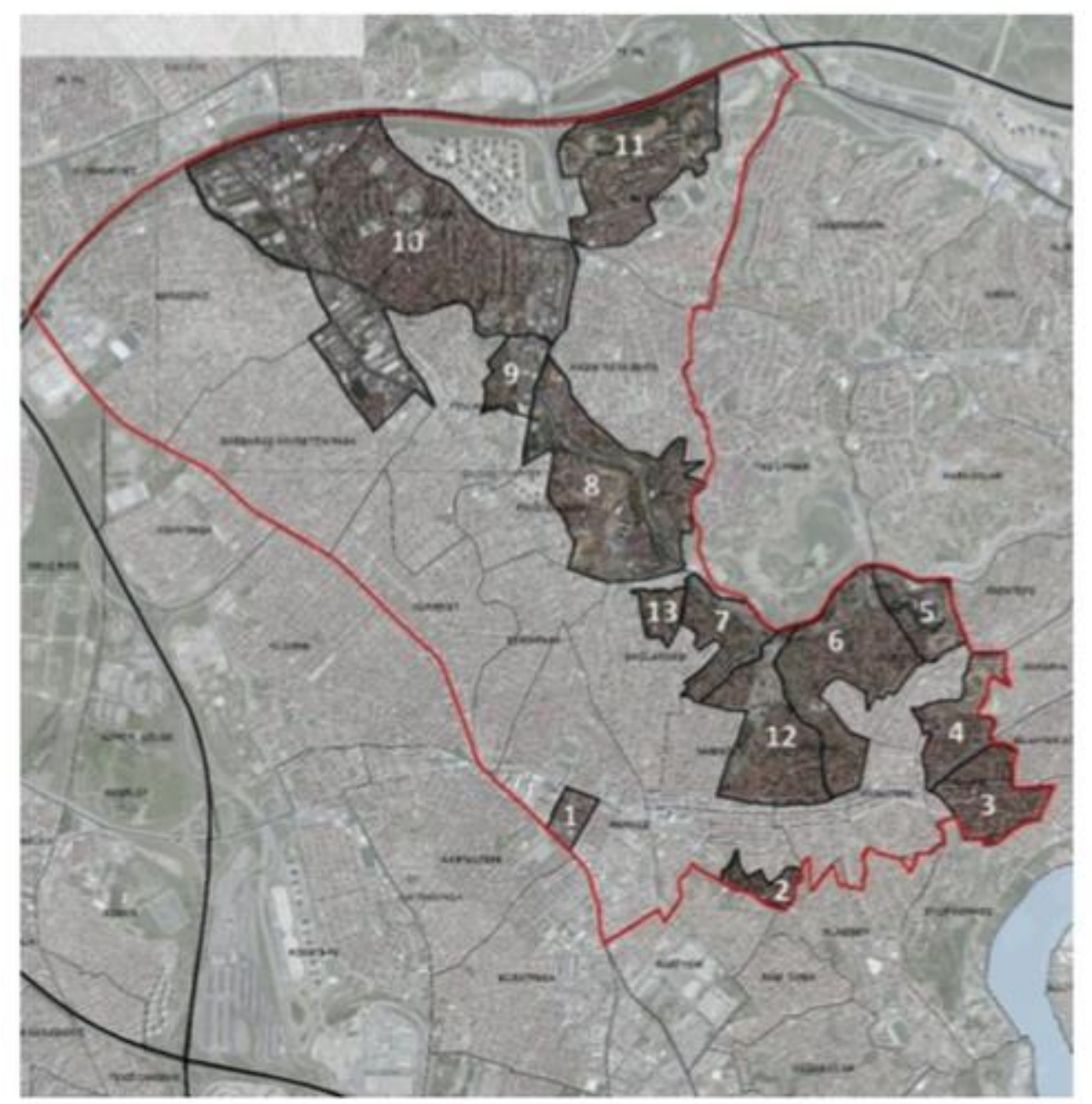

Source: KEYM 2015

Urban Regeneration Processes in Gaziosmanpaşa-Sartgöl

Sarıgöl-Yenidoğan URA is one of the gecekondu areas in the district which covers parts of both Sarıgöl and Yenidoğan Neighbourhoods. The 23 hectare-area is located on the south of the district close to the district centre. There are 1488 buildings and 1996 dwellings within the area. The building stock comprises of a combination of low-rise gecekondu with gardens and some old multi-storey apartments, the product of gecekondu redevelopment (Figure 5). However, there are problems with urban services, community facilities and infrastructure. The area is also associated with illegal activities such as drug dealing. Unemployment is another key problem. 
In the 1980s, gecekondu dwellers in the area were amongst those who gained the right to title deeds via Amnesty Laws. Some of them got their title deeds by paying the necessary fees but some could only get pre-title deeds or just zoning status documents. The low income residents of the neighbourhood therefore have a variety of levels of ownership rights. Three main social groups live in the area; immigrants from Bulgaria and Yugoslavia, migrants from the Black Sea Region and members of the Roma community, some of whom had been displaced by the redevelopment Sulukule (Basin 2014).

Urban regeneration in Sarıgöl can be analysed in three stages. The first stage began in 2005 when Gaziosmanpaşa Municipality designated 5 neighbourhoods including Sarıgöl, based on the Municipality Law no. 5393. The Mayor said that they were not going to force residents to demolish their houses as long as they have title deeds (İnce 2013a). A few gecekondu houses were demolished. But the designation was cancelled in 2007 (Akkoyunlu 2013).

The second stage began in 2010 when the 285 ha. site in Sarıgöl was designated as a Gecekondu Redevelopment Area again by the local municipality, based on Gecekondu Law no. 775. Initially, the Municipality worked in partnership with TOKI, and then TOKI was replaced by a private construction company. The Municipality revised the existing district plan, increasing the plot ratio and cancelling the height limit, which increased development rights and the density of redevelopment. The outcome was a proposal for 725 replacement houses in high-rise blocks. But the Chamber of Urban Planners (ŞPO) took the plan revision to court in 2011, based on concerns about the lack of provision of transportation infrastructure and community facilities. The court has not ruled on it yet (Ince 2013b).

In the meantime, most of the residents had only pre-titled deeds and thus were not accepted as "rightful owners". They were forced to sell their houses to the municipality for very low prices and leave their neighbourhood out of fear of expropriation. The tenants had no choice but to leave. Some 600 houses have been evacuated and demolished (Todays Zaman 2013).

In the beginning, it was announced by the Municipality that the replacement housing to be constructed in the Redevelopment Area would be sold to Gaziosmanpaşa residents only. But it was announced in November 2013 that sales would be open to the public (Todays Zaman 2013). Apparently, this was because owners could not afford and/or did not want to buy the replacement housing (Çatı 2015). 
Figure 5. Sarıgöl-Yenidoğan Urban Regeneration Area
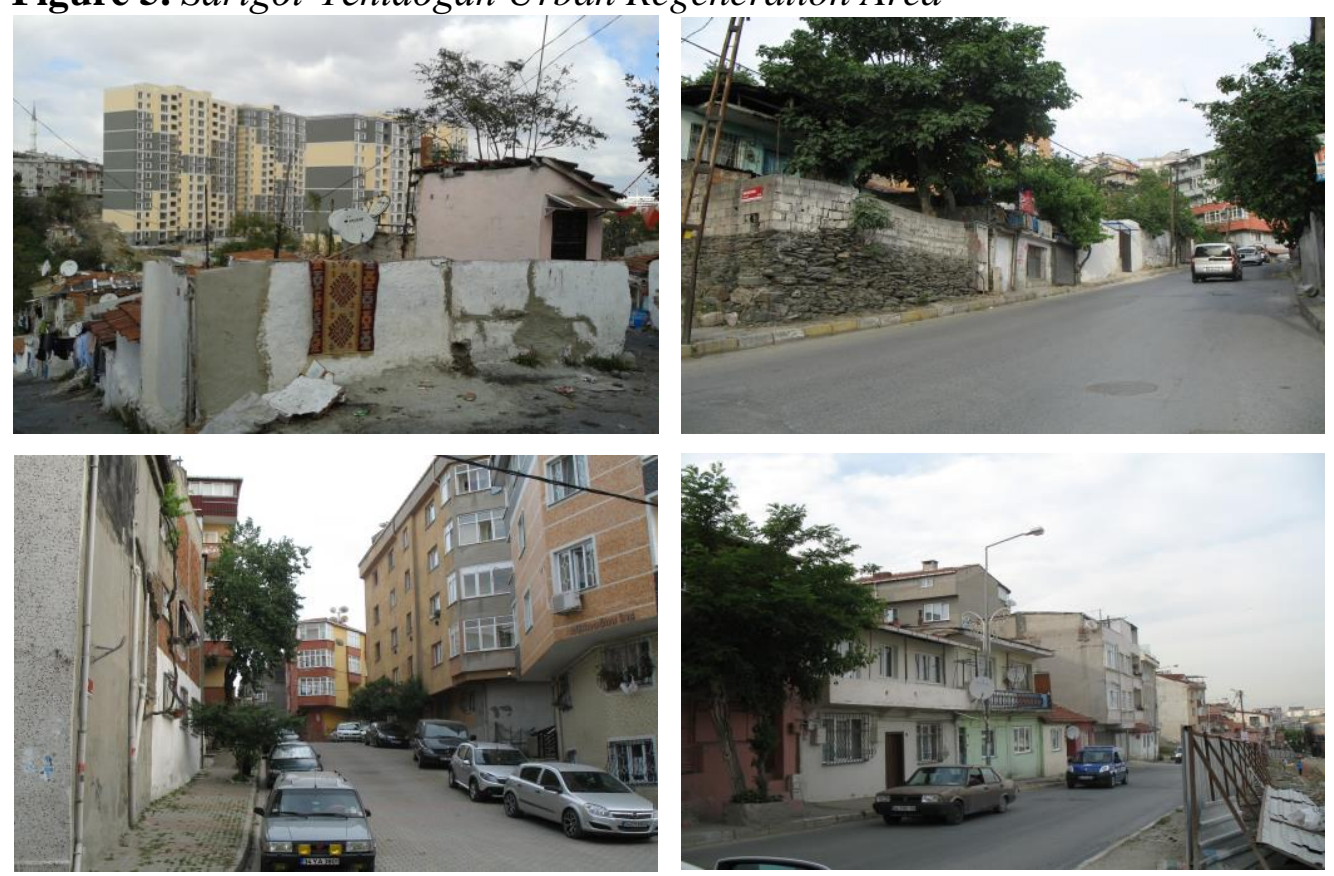

Although the Mayor had said that the 2012 Urban Regeneration Law was not going to be implemented in Gaziosmanpaşa (İnce 2013a), the rest of the Sarıöl-Yenidoğan Area was designated as a URA by the MEU in December 2013, using the new powers. This marked the beginning of the third and the current stage.

After designation, all powers were delegated to the district Municipality. The negotiation process in this third stage is the responsibility of GOPAS, an arms-length company of the Municipality. GOPAS commissioned KEYM, a private company, to deal with negotiations as well as the urban planning and design phase (Bölükbaş1 2014). KEYM stated the work in June, 2012. The Municipality opened a local office in the area where KEYM employees provide information about the project to the residents.

The project is being developed and will be implemented in 5 phases (Figure 6). The plan and the urban design project for the whole area were prepared by KEYM planners and architects and approved by the Ministry in July 2014. Architectural design is contracted to private architectural companies. Demolitions in Phase 1 and 2 have been completed. There are 3000 houses in the area and 130 tenants. Residents with pre-title deeds get half of the compensation given to residents with title deeds. Tenants receive a one-off rent support of 500TL (Baykal 2014). 
Figure 6. Sarlgöl-Yenidoğan URA Project Phases

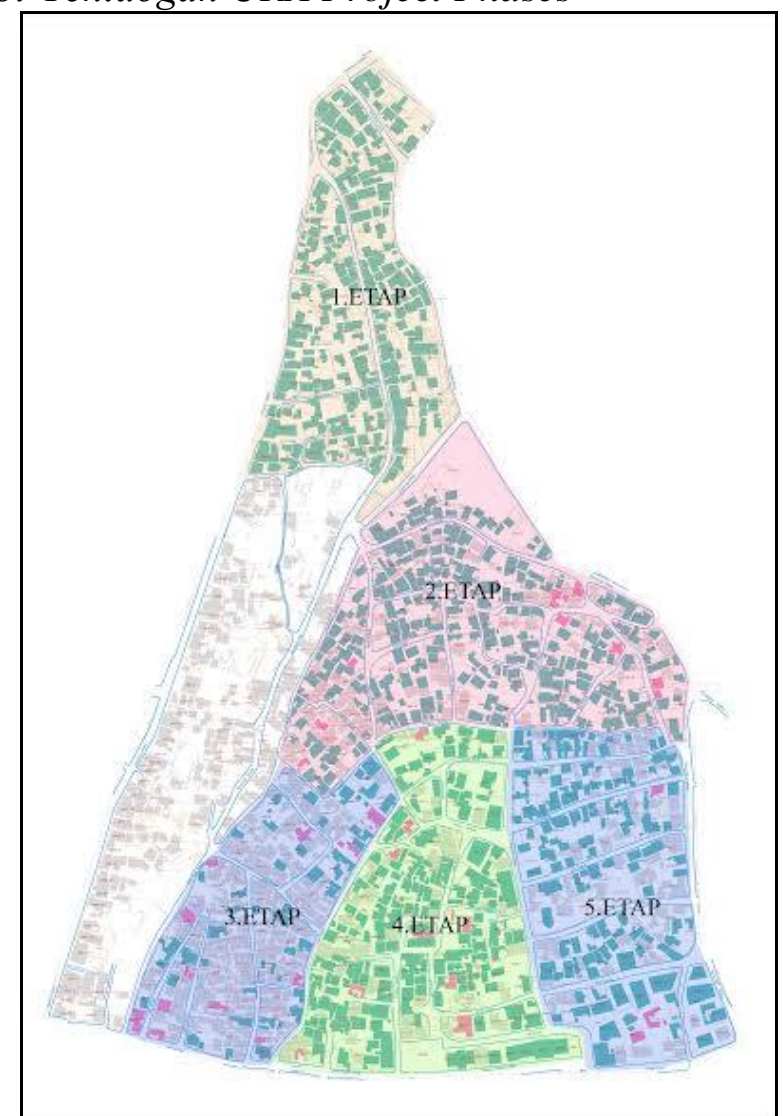

Source: Acquired from KEYM Sarıgöl office during interview with H Baykal

Owners are called to meetings individually and there are suspicions that not every family is offered the same deal. At the meetings, only urban design projects are shared with residents. When they ask about the location of their new house, they get a vague description such as one street up or one street down from where they live (Bozkurt 2014). In this context, residents established a neighbourhood association in February 2014. The Association took the designation to court. The court ruled in their favour and cancelled the designation in December 2014 on the grounds that there had been an inadequate assessment of earthquake risk. The next stage in the redevelopment process has yet to be determined.

\section{Discussion and Conclusions}

This final section discusses some of the key issues which will be the focus of the ongoing research and presents some interim conclusions which will be developed in the final stages of the research in 2016.

The analysis of the legacy of post war Turkish urbanisation processes identified the specific features which explain why major programmes of neighbourhood redevelopment are necessary but, to date, proving extremely 
controversial to develop and deliver. The research has identified a typology of physically, socially and economically diverse neighbourhoods, subject to varying degrees of earthquake risk, which are the target of the new legal and institutional framework of urban regeneration. This typology could be elaborated to establish the criteria for the choice of the areas that will be designated as URAs and their priority order for implementation in municipal neighbourhood regeneration programmes. Such an innovation would significantly improve current URA selection processes which are not transparent.

Currently municipalities submit applications for the designation of URAs for approval by the central government - the Ministry of Environment and Urbanism. These applications are not the subject of any consultation and are based on very limited analysis of physical, social and economic conditions in the neighbourhoods included, and there is no assessment of the potential impact of redevelopment (Yalçıntan 2012). This is an issue at a national and strategic level as emerging research shows that national policy which officially targets high earthquake risk areas is so far failing to do that. At a local and implementation level, residents are often unaware of a central government decision that their neighbourhood will be demolished until they become embroiled in negotiations with municipal officials and /or the representatives of construction companies which require them to provide proof of their property rights.

By definition, urban regeneration requires the restructuring of the ownership of land and buildings. The post-war urbanisation of Turkey, in combination with the Turkish inheritance laws has produced a complex array of different levels of property rights. Acting within the legal and institutional framework in place prior to the 2012 law, municipalities acquired full title to the land and buildings, through a combination of negotiation and expropriation and demolished the buildings. The land was typically sold to TOKI or a construction company which rebuilt the area to provide the re-placement housing. Only those residents with full title were entitled to be offered the full market value of their property and the opportunity to purchase an alternative property, either in their redeveloped neighbourhood or elsewhere. Compensation for other residents with different property rights was the subject of individual negotiation. Residents under threat of expropriation were effectively forced to sell and move out of their neighbourhood and tenants were the victims of forced eviction from their homes. This was the authoritarian and coercive process at the heart of the controversial redevelopment of Sulukule, characterised as "planned gentrification" (Kocabas and Gibson 2011).

The case study demonstrates that a version of this approach to neighbourhood redevelopment was developed in Sarıöl using powers available prior to the 2012 legislation. Low income Sarıgöl residents have varying levels of ownership rights ranging from full legal title to zoning status documents. In the area of Sarıgöl designated for redevelopment in 2010, the majority of residents had only pre-title deeds and were not accepted as "rightful owners". As in Sulukule they faced expropriation and the result of the 
negotiation process was that they were forced to sell their homes cheaply to the municipality and leave the neighbourhood, along with tenants who had no property rights. This narrow definition of what may be considered a fair deal for the existing residents is the basis of opposition to neighbourhood redevelopment. Thus the question of the "legitimacy" of the basis on which families occupy their apartments is a core issue.

Some 600 dwellings have so far been demolished to make way for the construction of 725 dwellings in high rise blocks. However, the urban design and planning work all took place "behind closed doors" and maximised housing provision. The related lack of provision for transport and community facilities prompted the Chamber of Planners to challenge the plan in the courts in 2011. Thus five years after the municipality designated this area for redevelopment hundreds of houses have been demolished but the completion of the scheme remains uncertain.

This experience points to the need for our research to further investigate the development economics underpinning this model of neighbourhood regeneration. Municipality negotiations with owners are driven by the need to assemble the land for transfer to a construction company at the lowest possible cost. Minimal provision of transport and community facilities maximises the number of dwelling units that can be provided within the constraints of plot ratio and building height requirements. Low land costs, maximum dwelling density and modest standards produce the most profitable contract conditions for the construction company and thus re-building is "commercially viable" at high rates of profit. Thus this model can provide modern, modest standard replacement dwellings within the means of households with middle incomes but unaffordable for poor families. There are variations of this model, not least in attractive locations where higher standard, more expensive dwellings can be produced for higher income families, in commercially successful developments.

The overall outcome of applying this model is the transfer of land from poor families to families with higher incomes in a process which generates high rates of profit for developers and contractors. Thus when the Gaziosmanpaşa Municipality began property acquisition negotiations in 2010, it announced that only Gaziosmanpaşa residents would be able to buy the replacement housing. Two years later it announced that the sales would be on the open market, apparently because local residents could not afford or did not want to buy the type of replacement housing which, by that time, was being proposed. This was despite the low land costs resulting from the restricted definition of legitimate property rights to holders of full title deeds, and the plan provision for high density housing. The definition of a commercially viable scheme apparently required a rate of profit for the construction company which could only be achieved by selling houses at a price beyond the means of the Gaziosmanpaşa residents. Thus unless there are major revisions, the overall result will be the displacement and dispersal of the existing residents and their replacement by a higher income group - an outcome which will be a variant of the "planned gentrification" of Sulukule. 
In December 2013, the Ministry of Environment designated the rest of the Sarıgöl-Yenidoğan Area as a URA, using the new powers of the 2012 Urban Regeneration Law. A key research question is whether the changes in the legal and institutional framework will enable a revised model to be developed which will deliver different outcomes from those resulting from the Sarigöl redevelopment which was initiated before 2012. Critics have argued that the new legislation was primarily designed to boost the construction industry output as a response to the downturn in the Turkish economy resulting from the global financial crisis (Balaban 2013, Özkan Eren and Özçevik 2015). Hence, the new legal and institutional framework provides maximum incentives for private construction companies to work with municipalities to develop and implement highly profitable residential development projects. In this view the application of models based on the new law will have the same negative impact on residents in the URAs as previous models.

The validity of this view will be empirically tested in the case study. There is evidence of changes of approach in the URA. A single company has been commissioned to do both the negotiations to assemble the site and the urban design and planning work, with a local office to improve communications with residents. Some of the terms of the negotiations are clearer: residents with pretitle deeds are now eligible for half the compensation given to those with full title deeds and tenants get a one-off rent support payment of 500TL to cover moving costs and initial rent in an alternative apartment. A phased approach opens up the possibility of short distance local re-housing for at least some residents. But the negotiation process remains controversial, not least the definition of legitimate property rights. The re-housing process is not transparent. Faced with this situation the Neighbourhood Association has secured the cancellation of the URA designation.

Our further work will continue to monitor and evaluate the application of the 2012 model in Sarıgöl. This will draw on experience in western developed countries where resident participation has gradually become an integral part of neighbourhood regeneration and has had a positive impact, despite being shaped and constrained by neo-liberal urban policies (Gökşin 2008). The level of participation varies but there is evidence that participatory partnership working can deliver an inclusive and socially sustainable approach (Gibson 2012).

This further work will provide evidence of the costs and benefits for all stakeholders - the residents, the municipality and the construction industry - of the model which is currently being applied in Gaziosmanpaşa. This evidence will underpin the key features of a revised model which the research will propose. The research evidence to date has demonstrated the need for more transparency in the selection and prioritisation of URAs and the provision of affordable replacement housing for apartment owners, together with the social rented housing for tenants. Such reforms will require further changes to the legal and institutional framework based on the experience of implementing the first generation of URAs. At district and neighbourhood levels changes are needed to establish trust in a redevelopment process which will minimise 
displacement. This will involve establishing the varied housing needs of residents and creating a range of housing options that enable these needs to be met locally. Thus the research aims to define and contribute to a process which will establish a participatory, community-based approach to neighbourhood redevelopment - the antithesis of the models developed and applied in the decade since neighbourhood redevelopment first emerged in Turkish cities.

\section{References}

AGFE Mission (Advisory Group on Forced Evictions) (2009) Report to the Executive Director of the UN-HABITAT Program-Mission to Istanbul. Retrieved from http://bit.ly/1OIoybL.

Akkoyunlu N (2013) Şen Mahalle'de açılımlı dönüşüm ve kentsel yalanlar [Regeneration and urban lies in Şen Neighbourhood]. In A Koca, CO Calıskan, E Kaya, G Akgun (Eds) Kentleri Savunmak (Defending Cities). Istanbul: Notabene Publishing.

Balaban O (2013) Neoliberal yeniden yapılanmanın Türkiye kentleşmesine bir diğer armağanı: kentsel dönüşümde güncelin gerisinde kalmak [Another gift of neoliberal re-structuring to Turkish urbanisation: falling behind the current discussion in urban regeneration]. In A Çavdar, P Tan (Eds) Istanbul: Müstesna Kentin Istisna Hali [Istanbul: Exceptional State of the Extraordinary City], 5178. Istanbul: Sel Yayıncilık.

Balamir M (2006) Dönüşüm Alanları Hakkında Kanun Tasarısı'na ilişkin görüşler [Views on Law about Regeneration Areas]. CHP Yerel Yönetimler Dergisi, 13(December 2006): 47-59.

Basın Ü (2014) Ünal Basın ile mülakat, Sarıgöl Mahallesi muhtarı [Interview with Ünal Basın, Sarıgöl Neighbourhood headman] 19.12.2014.

Baykal H (2014) Hazal Baykal ile mülakat, KEYM Sarıgöl Ofisi Ş.Plancıs1 [Interview with Hazal Baykal, KEYM Sarıgöl Office, U. Planner] 29.05.2014.

Bektaş Y (2014) Bir kentleşme stratejisi olarak yasanın kentsel mekanı dönüştürmedeki etkisi: Ankara örneği [The effect of law in the transformation of the urban space as an urbanization strategy: the case of Ankara]. Planlama 24(3): 157-172. DOI= 10.5505/planlama.2014.83803.

Bozkurt C (2014) Cemile Bozkurt ile mülakat, Gaziosmanpaşa Sarıgöl Mahallesi Koruma Yardımlaşma ve Dayanışma Derneği üyesi [Interview with Cemile Bozkurt, Gaziosmanpaşa Sarıgöl Neighbourhood Preservation and Solidarity Association Member] 19.12.2014.

Bölükbaşı A (2014) Abdullah Bölükbaşı ile mülakat, Gaziosmanpaşa Belediyesi Kentsel Dönüşüm Bürosu Şefi [Interview with Abdullah Bölükbaş1, Gaziosmanpaşa Municipality Urban Regeneration Office Chief] 29.05.2014.

Buğra A (1998) The Immoral Economy of Housing in Turkey. The International Journal of Urban and Regional Research 22(June 1998): 303-317.

Can C (2013 July 21). Sulukule residents given new homes but project incomplete. Todays Zaman. Retrieved from http://bit.ly/1ggWNpD.

Çatı Ş (2014) Şadi Çatı ile mülakat, Sarıgöl Romanlar Yardımlaşma ve Dayanışma Derneği eski başkanı [Interview with Şadi Çatı, Sarıgöl Roma Solidarity Association former chairman] 19.12.2014. 
Vol. 2, No. 1 Gökşin et al.: The Origins, Processes and Emerging Outcomes...

Cumhuriyet Gazetesi (2015, March 6) Japonların deprem haritası Bakanlığın haritasıyla uyuşmuyor [Earthquake map of the Japanese do not match with the Ministry's]. Cumhuriyet Gazetesi. Retrieved from http://bit.ly/Ovixmr.

Dülgeroğlu Y et al. (2013) Urban transformation developments triggered by new legal regulations in Istanbul. Paper presented at the 39th Intl. IAHS World Conference on Housing Science, "Changing Needs". Milan, Italy, September16-20, 2013.

Dündar Ö (2001) Models of urban transformation: informal housing in Ankara. Cities 18(6): 391-40.

Enlil ZM (2011) The neoliberal agenda and the changing urban form of Istanbul. International Planning Studies 16: 5-25.

Gapinsaat.com (2015) Tarlabaşı Urban Renewal Project [online] Retrieved from http://bit.ly/1FT6edn. [Accessed 21 Sep. 2015].

Gaziosmanpasa.bel.tr (2015) T.C. Gaziosmanpaşa Belediyesi [Gaziosmanpaşa Municipality] [online] Retrieved from http://gaziosmanpasa.bel.tr/ [Accessed 21 September 2015].

Gibson M (2012) Urban regeneration in England- evolving investment partnerships. In Proceedings of 2011 Housing Convention (Istanbul, Turkey, March 04-05, 2011). TOKI, Ankara: 252-267.

Gibson M, Goksin ZA (2009) Neighbourhood regeneration challenges, progress and prospects in Istanbul: a neighbourhood capital perspective. Paper presented at the $I^{\text {st }}$ International Neighbourhood Renewal Conference (London, UK, November, 19-20, 2009).

Gibson M, Kocabas A, Goksin A (2010) A reappearing faultline. Planning, 12 February.

Gökşin ZA (2008) Sürdürülebilir Mahalle Yenileşmesinde Toplum-tabanlı Model: Kadiköy-Fikirtepe için bir Model Önerisi [Community-based Approach in Sustainable Neighbourhood Regeneration: A Model Proposal for KadikoyFikirtepe]. Doctoral Thesis. Reference no. 333397. Mimar Sinan Fine Arts University.

Güneş E (2012 October 6) Strong explosions kick off huge urban transformation. Hurriyet Daily News. Retrieved from http://bit.ly/1OIsysD.

IBB-JICA (2002) The Study on A Disaster Prevention / Mitigation Basic Plan in Istanbul including Seismic Microzonation in the Republic of Turkey. Final Report, IBB, İstanbul.

İnce E (2013a March 20) Gaziosmanpaşa afet yasasına 'alternatif' geliştirdi [Gaziosmanpaşa developed "alternative" to disaster law]. Radikal. Retrieved from http://bit.ly/1QMhFDW.

İnce E (2013b April 5) Şen Mahalle' ikinci Sulukule mi? [Is Şen Neighbourhood the next Sulukule?]. Radikal. Retrieved from http://bit.ly/1KNMiaB.

Kahraman T (2013) Kent hukukunun yeni yüzü: Düzenleyici devletten seçkinleştirici devlete [New face of city law: from regulatory state to gentrifying state]. In A Çavdar, P Tan (Eds) Istanbul: Müstesna Kentin Istisna Hali [Istanbul: Exceptional State of the Extraordinary City], 17-48. Istanbul: Sel Yayınc1l1k.

Keleş R (1997) Kentleşme Politikası-4. Baskı [Urbanisation Policy $-4^{\text {th }}$ Edition], Istanbul: Imge Kitabevi.

Keyder Ç (1999) The housing market from the informal to the global. In C Keyder (Ed) Istanbul: Between the Global and the Local, 143-160. USA: Rowman \& Littlefield Publishers.

KEYM Kentsel Yenileme Merkezi [Urban Renewal Center]. Retrieved from http://bit.ly/1FJVKNb. 
Kocabas A, Gibson MS (2011) Planned gentrification in Istanbul: the Sulukule renewal area 2005-2010. Int. J. Sus. Dev. Plann 6(4): 420-446.

Kuyucu T, Ünsal Ö (2010) "Urban transformation" as state-led property transfer: an analysis of two cases of urban renewal in Istanbul. Urban Studies 7 (June 2010): 1479-1499.

Myworld-europe.com (2015) My World Europe. Retrieved from http://bit.ly/1P6SEoz [Accessed 21 September 2015].

Oktem Unsal B (2015) Impacts of Tarlabasi Urban Renewal Project: (Forced) eviction, dispossesion and deepening povery. In O Ozcevik, CA Brebbia, SM Sener (Eds) Sustainable Development and Planning VII. UK.

Özden PP (2008) Kentsel Yenileme [Urban Renewal]. Istanbul: Imge Kitabevi.

Özkan Eren M, Özçevik Ö (2015) Institutionalization of disaster risk discourse in reproducing urban space in Istanbul. ITU AIZ, 1 (March 2015): 221-242.

Prime Ministry (2005a) Kentsel Dönüşüm ve Gelişim Yasası Taslağ1 [Draft Urban Regeneration and Development Law]. Retrieved from http://bit.ly/1KTbw54.

Prime Ministry (2005b) Yıpranan Tarihi ve Kültürel Taşınmaz Varlıkların Yenilenerek Korunması Ve Yaşatılarak Kullanılması Hakkında Kanun [Law on Renovating, Conserving and Actively Using Dilapidated Historical and Cultural Immovable Assets]. Retrieved from http://bit.ly/1 Vp2xDb.

Official Gazette (2012) Afet Riski Altındaki Alanların Dönüştürülmesi Hakkında Kanun [The Law of Transformation of Areas under the Disaster Risks]. Retrieved from http://bit.ly/1O4pK7K.

ŞPO (2011) 648 sayılı kanun hukmunde kararname değerlendirmesi [Evaluation of Decree Law no. 648]. Retrieved from http://bit.ly/1KUh7Y5.

Tekeli I (1994a) The Development of the Istanbul Metropolitan Area: Urban Administration and Planning. Istanbul: Kent Publishing.

Tekeli I (1994b) Gecekondu. In Dünden Bugüne İstanbul Ansiklopedisi 1st ed, 381385. Istanbul: Kültür Bakanlığ ve Tarih Vakfi.

Todays Zaman (2013 October 26) Gaziosmanpaşa's vice mayor defends development projectwith racial slur. Todays Zaman. Retrieved from http://bit.ly/1O9FGqS.

Töre E (2015) Dönüşümün ekseninde ihtilaflı bir sektör: "emlak" gölgesinde "yeni" bir Istanbul'a doğru [A controversial sector in the midst of regeneration: towards a "new" Istanbul overshadowed by "property"] . Mimar-ist 52 (Winter 2015), 3038.

Türkün A (2014) (Ed) Mülk, Mahal, İnsan- İstanbul'da Kentsel Dönüşüm [Property, Place, People-Urban Regeneration in Istanbul]. Istanbul: Istanbul Bilgi University Publications.

Türkün A, Aslan S (2014) Ayazma ve Tepeustu'nden Bezirganbahce'nin "konut depolarına"- mekanı değişen yoksulluk [From Ayazma and Tepeustu to Bezirganbahce's housing depots - spatially displaced poverty]. In A Türkün, (Ed) Mülk, Mahal, Insan- İstanbul'da Kentsel Dönüşüm [Property, Place, PeopleUrban Regeneration in Istanbul], 354-389. Istanbul: Istanbul Bilgi University Publications.

Wikipedia (2015) Gaziosmanpaşa. Retrieved from http://bit.ly/1KU6Rin.

Yalçıntan MC (2012) Afet Yasasının İlk Kentsel Dönüşüm Projesi [The first Project of the Disaster Law]. Retrieved from http://bit.ly/1Vp3xHl. 
